\begin{tabular}{|l|l|l|l|l|}
\hline Cuadernos de Investigación Geográfica & 2001 & $\mathbf{N}^{\circ} 27$ & pp. 79-93 & ISSN 0211-6820 \\
\hline
\end{tabular}

(c) Universidad de La Rioja

\title{
RUNOFF GENERATION ON ABANDONED FIELDS IN THE CENTRAL EBRO BASIN - RESULTS FROM MODELLING
}

\author{
MANUELSEEGER ${ }^{(1)}$ \\ JOHANNES B. RIES (2)
}

(1) Instituto Pirenaico de Ecología, CSIC, Apartado 202, 50080 Zaragoza, Spain.

(2) Institut für Physische Geographie, Johann Wolfgang Goethe Universität, Senckenberganlage 36, 60325 Frankfurt am Main, Germany.

ABSTRACT: The results from several rainfall simulations performed on two abandoned fields of different ages in the Central Ebro Depression have been analysed by application of the physically based hydraulic model HILLFLOW 1D. The data gained by the simulations was used to parame terise the model. Afterwards, the runoff generation characteristics were determined by simulation of different rainfall intensities and different macroporosities of the soil. The young fallow land shows a minimum inten sity for runoff generation of $6 \mathrm{~mm} \mathrm{h-1.} \mathrm{An} \mathrm{increase} \mathrm{of} \mathrm{the} \mathrm{rainfall} \mathrm{intensity}$ leads rapidly to a growing runoff coefficient, being the value modelled for $30 \mathrm{~mm} \mathrm{~h}-1$ nearly the same as the simulated one (40 mm h-1). Another con clusion of the simulations and their modelling is the homogeneity of the soils on the young fallow land, with no macroporosity all over the profile. On the other hand, the rainfall simulations and the modelling on the old fallow land show a high variability of rainfall-runoff response patterns, strongly conditioned by the presence of macropores. They are distributed very irregularly throughout the soil of the old fallow land. In both cases, water infiltrates only little into the soil matrix, for that measures for enhan cing soil hydraulic properties are needed.

RESUMEN: Se han analizado los resultados de numerosas simulacio nes de lluvia en campos abandonados de diferente antugüedad en la Depresión central del Ebro aplicando el modelo hidrológico de base físi ca HILLFLOW 1D. Los datos de las simulaciones se utilizaron para parametrizar el modelo. A continuación, las características de la generación de escorrentía se analizaron modelizando diferentes intensidades de lluvia y volúmenes de macroporos en el suelo. En el campo recientemente aban donado se pudo calcular una intensidad de llluvia mínima para la gene ración de escorrentía de $6 \mathrm{~mm}$ h-1. Una intensidad de precipitación cre ciente produce un incremento muy fuerte del coeficiente de escorrentía, de modo que precipitaciones de $30 \mathrm{~mm} \mathrm{h-1} \mathrm{se} \mathrm{diferencian} \mathrm{poco} \mathrm{de} \mathrm{las} \mathrm{simu} \mathrm{-}$ ladas con $40 \mathrm{~mm}$ h-1. Otra conclusion es que los suelos del campo recientemente abandonado son muy homogéneos y están caracterizados por la ausencia de macroporos. La respuesta de la generación de escorrentía a la precipitación es en cambio muy variable en el campo abandonado anti - 
guo. Aquí, toda respuesta depende de la macroporosidad del suelo, de dis tribución muy irregular. En ambos casos, la infiltración al materal matri cial del suelo es muy escasa, de modo que son necesarias medidas para mejorar las características hidráulicas de estos suelos.

Key-words: Rainfall simulation, Abandoned fields, Hydrological modelling, Soil Hydrology, Runoff generation, Ebro Depression.

Palabras clave: Simulación de lluvia, Campo abandonado, Modelo hidrológico, Hidrología del suelo, Generación de Escorrentía, Depresión del Ebro.

\section{Introduction}

The use of rainfall simulations to understand processes of runoff-generation and erosion has found a widespread use during the last decades. Its applications, possibilities and limitations are resumed by Cerdà (1999). In areas where soil water is the limiting factor to plant growth and vegetation succession to recolonise abandoned farmland, there is a need to understand the infiltration processes and the water movement during rainfall events into the soil. The experimental design for this purpose is complicated and would reduce considerably the possible number of experiment repetitions, introducing systematic errors, especially at low rainfall intensities. In addition, saline and gypsiferous soils show some complications for accurate soil-water measurements with gravimetric methods or Time-Domain-Reflectometry (TDR) (NSSC, 1996; Soilmoisture Inc., 1990).

The present combination of a large number of rainfall simulations (presented by here Ries and Langer, 2001), detailed soil mapping and physical characterisation of the soils (Seeger, 2001) give the possibility to parameterise with a high accuracy the model input and, at the same time, quantify the processes in the soil at every moment of the simulation. Parting from this, an extrapolation of the processes to other events with different rainfall characteristics is possible.

The aim of this work is, at one hand, to parameterise a physically based model, to explain with this the processes of infiltration and runoff-generation and, on the other hand, to identify the factors influencing these processes. In addition, this study may elucidate the possibilities and limitations of this kind of models as well as indicate some strategies to mitigate the constraints of the soils to water recharge.

\section{The study area}

The dominating soils are a Hyperochric Gypsisol on the young fallow land, closely associated to Leptic Gypsisols and Gypsiric Leptosols, depending on the depth of the tertiary gypsum bank, and a Haplic Gypsisol on the old fallow land.

Characteristic for the soil surface of the young fallow land is a 0.5 to $2 \mathrm{~cm}$ thick soil crust, developing rapidly after only some rainfall events. The differentiation of the lower horizons is very weak and can only be done in the field by changes in soil structure (see Table 1); subangular in the topsoil and platy and/or without structure beneath $30 \mathrm{~cm}$ depth. The whole area is characterised by a very low content in organic carbon $(<0.4 \%)$ 
Table 1. Brief profile description of the Hyperochric Gypsisol on the "young fallow land". Texture class and structure according to Schoenenberger et al. (1998), pore density to AG Boden (1994)

\begin{tabular}{|ccccccccc|}
\hline Horizon & depth & $\begin{array}{c}\text { Texture } \\
\text { class }\end{array}$ & structure & pores & pH & CaSO4(\%) & Corg(\%)CaCO3 (\%) \\
\hline Apm & 2 & SL & $\mathrm{m}$ & none & 7.7 & 20.4 & 0.38 & 10.5 \\
Ap1y & 15 & SL & gr/sbk & low & 7.4 & 17.6 & 0.30 & 10.6 \\
Ap2y & 30 & SL & sbk & very low & 7.2 & 19.9 & 0.25 & 11.2 \\
2Cd & 60 & SL & pl & none & 7.2 & 8.4 & 0.10 & 8.4 \\
\hline
\end{tabular}

and a slightly alkaline soil $\mathrm{pH}$ all over the soil depth. The gypsum-content decreases from about $20 \%$ in the upper $30 \mathrm{~cm}$ to less than $5 \%$ at about $60 \mathrm{~cm}$ depth. Phosphorous and Nitrogen content is low, whilst the amount of nutrients like Potassium and Magnesium reaches very high values, especially in the deeper soil horizons. The grain size of the fine material is dominated by silt (>70 \% in the upper $30 \mathrm{~cm}$, see Figure 1), with in increasing amount of clay with depth. Thus, the soil material is highly erodible.

The soils of the old fallow land have developed a crust, too, which is only $0.5 \mathrm{~cm}$ thin. The upper $28 \mathrm{~cm}$ show a good structure development (Table 2), with stable small subangular aggregates. Below the aggregates become very much bigger, but until a depth of $76 \mathrm{~cm}$ there is recognisable a structure development. Until this depth there could be observed roots in the profile, too. The soil organic carbon is only low in the crust, and extremely low below. The $\mathrm{pH}$ of the soil is about the same like in the young fallow land, but especially the gypsum content is here very much higher $(>25 \%)$. Or this, the soil solution is completely dominated by Calcium, whilst other nutrients show low to very low contents. The matrix is composed here by silt (Figure 2), too, which causes a high erodibility of the soil.

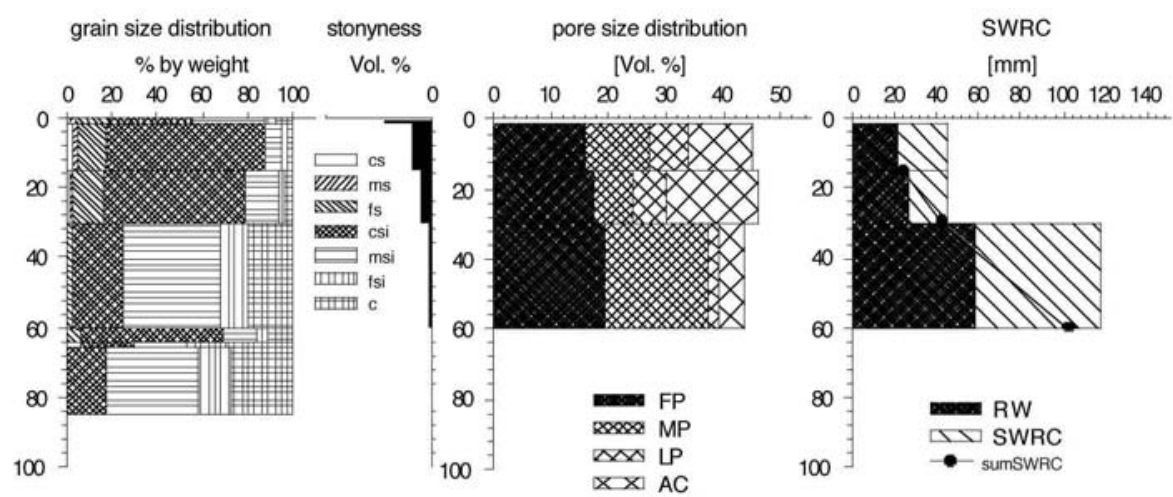

Figure 1. Physical soil characteristics of the Hyperochric Gypsisol on the young fallow land. On the right side the Soil Water Retention Capacity (RETC). 
Table 2. Brief profile description of the Haplic Gypsisol on the "old fallow land". Texture class and structure according to Schoenenberger et al. (1998), pore density to AG Boden (1994)

\begin{tabular}{|ccccccccc|}
\hline Horizon & depth & $\begin{array}{c}\text { Texture } \\
\text { class }\end{array}$ & structure & pores & pH & CaSO4(\%) & Corg(\%)CaCO3 (\%) \\
\hline Apm & 0.5 & SL & $\mathrm{m}$ & moderate & 7.6 & 30.0 & 1.02 & 12.3 \\
Apy & 28 & SL & gr/sbk & high & 7.7 & 35.6 & 0.40 & 11.0 \\
Cy1 & 52 & SL & sbk & moderate & 7.8 & 25.2 & 0.38 & 11.9 \\
Cy2 & 76 & SL & sbk & very low & 7.6 & 26.0 & 0.29 & 12.1 \\
$2 \mathrm{Cr}$ & $>76$ & SL & $\mathrm{m}$ & none & 7.5 & 39.1 & 0.17 & 4.1 \\
\hline
\end{tabular}

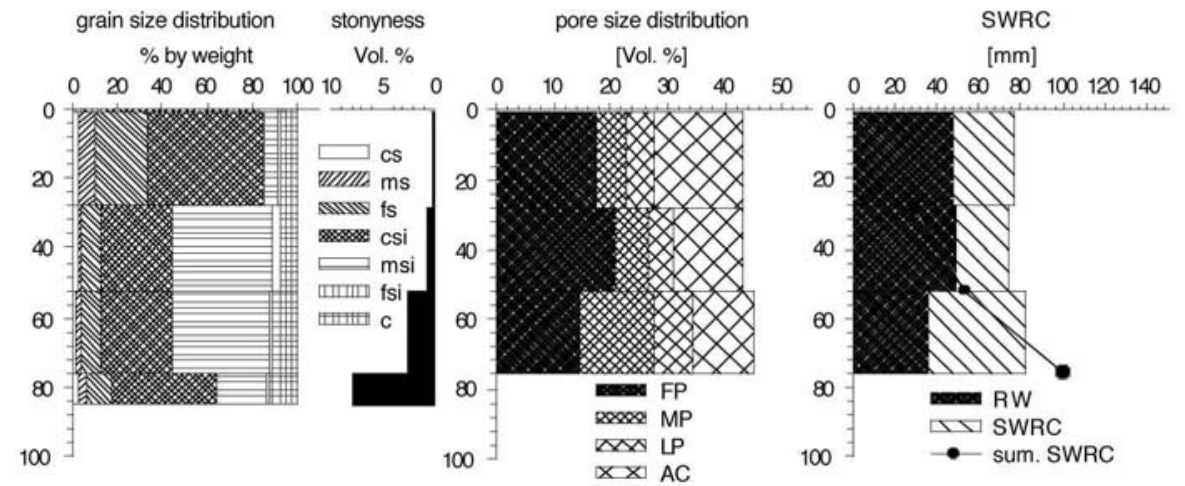

Figure 2. Physical soil characteristics of the Haplic Gypsisol on the old fallow land. On the right side the Soil Water Retention Capacity (RETC).

\section{Material and methods}

\subsection{Methods of physical soil characterisation}

Grain-size distribution was determined following the German Soil Survey Manual (AG Boden, 1994) by sedimentation, but without washing off the gypsum. Physical properties related to the pore distribution of the soils were measured in laboratory. For this, $100 \mathrm{~cm}^{3}$ soil cores were taken at the rooted horizons. Water content was measured gravimetrically at pF-values of 1.8, 2.0, 3.0 and 4.2, the last one was measured with disturbed soil samples, after water extraction by suction ( $\mathrm{pF} 1.8$ ) and pressure (all other $\mathrm{pF}$-values). In addition saturated hydraulic conductivity of all analysed horizons was measured with a falling head permeameter with water level gradients of 5,10 or $20 \mathrm{~cm}$, depending on the permeability of the soil. Water retention curves were adjusted according to van Genuchten (1980), with the RETC-program (van Genuchten et al., 1991).

In addition to the analyses in laboratory, infiltration measurements were done with a modified single-ring infiltrometer (Bork, 1988; Link, 1999). The data used 
correspond to the ones obtained after $180 \mathrm{~min}$ of experiment and corrected after Tricker (1978). These experiments included measurements of infiltration after removing the soil crust for the quantification of the influence of the soil crust on infiltration capacity of the soils.

\subsection{Rainfall simulations}

Rainfall simulations were performed with an improved plot rainfall simulator like it is frequently used in Spain (Calvo et al. 1988; Ruiz-Flaño 1993; Cerdà 1999). Its function is described with more details by Ries et al. (2000) and Ries \& Langer (2001, in this volume). The pressure-regulated jet-rainfall simulator generated a precipitation of an intensity of $40 \mathrm{~mm} \mathrm{~h}^{-1}( \pm 5 \%)$ during $30 \mathrm{~min}$ on a round plot with $60 \mathrm{~cm}$ of diameter and an area of $0.28 \mathrm{~m}^{2}$. The whole apparatus is covered by a plane so the influence of evaporation and especially of wind were turned off. Surface runoff was measured by capturing all runoff-water in bottles during 5 min intervals. The time when water appeared on the runoff funnel was recorded as runoff-begin. After the experiments the soil was digged to observe the infiltration depth and to install the TDR probes. Water content was measured with a Trase-TDR, for which the probes were placed horizontally into the soil at 3 and $9 \mathrm{~cm}$ depth.

In the years between 1995 and 1998 a total number of 13 simulations were done from which 6 simulations, performed between spring and autumn of 1998, were selected for this study. The plots of these experiments showed an inclination between $2^{\circ}$ and $7^{\circ}$, and a vegetation cover was less than $5 \%$, so interception effects were negligible.

\subsection{The HILLFLOW 1 D model}

For the modelling of the runoff and infiltration on the fallow-land in Maria de Huerva there was used the physically based model HILLFLOW 1 D (Bronstert, 1994). The limitation to a one dimensional model was imposed by the plot experiments (see Figure 3), and for this lateral water movements are not modelled. The theoretical bases of the model have been discussed widely by Bronstert (1994) and Bronstert et al. (1998). One of the characteristics of the model is the separation of the processes in the micro and macropore system. Water movement inside the micro pore system (soil matrix) is modelled by approximation of the Richards-equation (Richards 1931) and assuming the lower boundary of the modelled soil column to be above ground water level. Macro-pore flow is supposed to be non-Darcian and modelled with application of the concept of the "kinematic wave". Infiltration processes are modelled analogous: total infiltration is the sum of macropore- and matrix-infiltration, whilst the first is only active when the matricial infiltration capacity is exceeded by rainfall intensity. In the applied $1 \mathrm{D}$ model surface runoff was considered to be the rainfall excess on infiltration, and at the same manner the subsurface stormflow was regarded: excess of throughflow was considered as interflow and/or percolation to the deeper, not modelled soil horizons. 


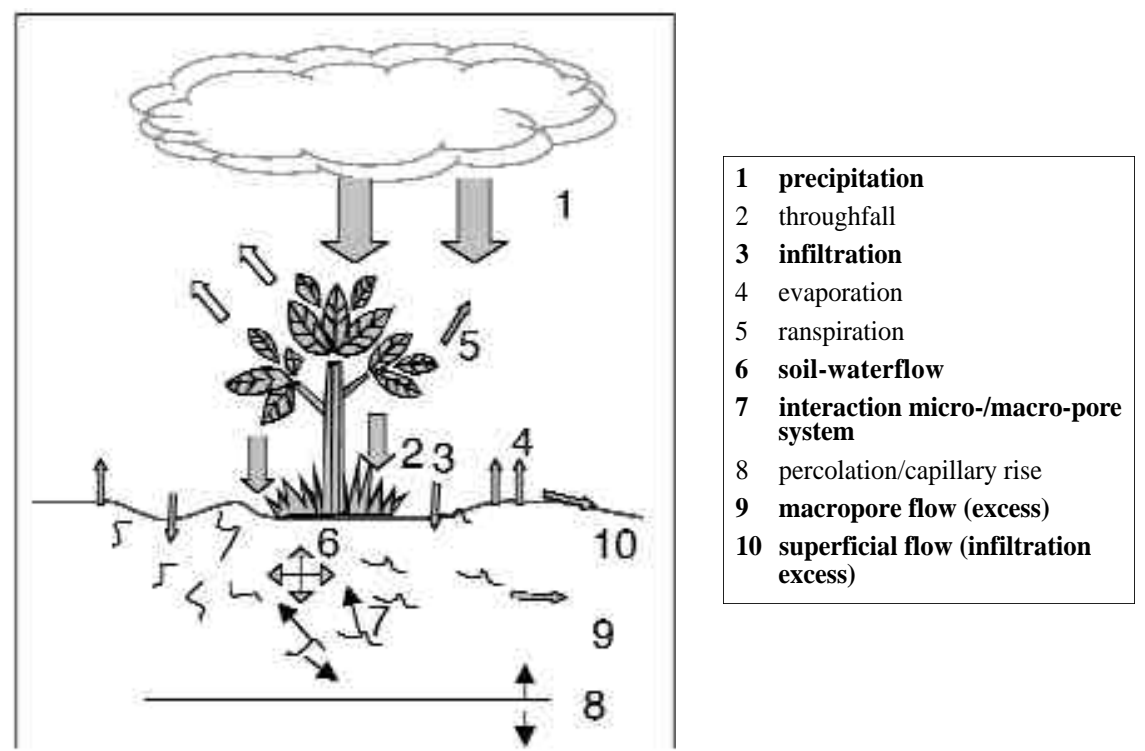

Figure 3. Scheme of the model HILLFLOW 1D. Bold letters for the processes modelled in this case.

The model output includes total infiltration rate and amount as well as a differentiation of infiltration into matrix and macro-pore system and the infiltration excess (considered here to be the runoff) in time steps of one minute. The soil water content of the different horizons is included into the output with time steps of $5 \mathrm{~min}$.

\subsection{Parametrisation of the model}

The model was parametrised by using the runoff and moisture measurements and observations of the rainfall simulations. Supported on their results some values of soil characteristics were adapted according to different observations in the field and laboratory measurements. An iterative approach was applied to approximate the runoff values calculated with the model to the ones measured during the rainfall simulations. The values of soil water content simulated and modelled were taken as control values to establish the validity of the model.

\section{Results}

\subsection{Rainfall simulations}

The rainfall simulations in Maria de Huerva are described in detail by Ries \& Langer (2001) in this volume. For this, the descriptions here are centred on some patterns relevant for comparing the simulated and modelled data.

The water content of the upper $5 \mathrm{~cm}$ of the Hyperochric Gypsisol of the soil was determined always less than $7 \%$, reaching even values lower than $2 \%$ before the simulation started. The beginning of the runoff was recorded in all simulations during the first 
5 min interval, ranging between $1 \mathrm{~min} 20 \mathrm{~s}$ and 3 min after the beginning of the experiment. The runoff coefficient was very high, ranging after $30 \mathrm{~min}$ of experiment between 0.65 and 0.81 . The observed infiltration depth never reached depths deeper than $7 \mathrm{~cm}$, being mostly at about $4 \mathrm{~cm}$. According to this the moisture values measured at $3 \mathrm{~cm}$ ranged at about $16 \%$ after rainfall simulation, whilst at $8 \mathrm{~cm}$ depth the water content never exceeded $9 \%$.

The simulations on the old fallow land, started at soil water contents between 4.3 and $7.4 \%$, show a high variability: the total runoff coefficients range between 0.19 and 67.2, the runoff starts between 3 and 15 minutes after simulation begin, and the depth of the water inflow into the soil ranges between 2 and $40 \mathrm{~cm}$.

\subsection{Soil physical characteristics and model input parameters}

The Hyperochric Gypsisol of the young fallow land is characterised by varying values of the hydraulic conductivity along the profile. Highest $\mathrm{K}_{\text {sat }}$-values were measured between 15 and $30 \mathrm{~cm}$ depth, where no sealing and crusting can occur (like in the horizon above). The decrease in $30 \mathrm{~cm}$ depth can be related to the low content of fast draining pores due to the development of a platy structure by ploughing compaction. Infiltration measurements on the surface show a very low infiltration capacity $(<5 \mathrm{~mm}$ $\left.\mathrm{h}^{-1}\right)$, which is considerably increased by removing the soil crust $\left(\sim 10 \mathrm{~mm} \mathrm{~h}^{-1}\right)$, about the same as the $\mathrm{K}_{\text {sat }}$-value measured in laboratory. The total porosity varies little between the horizons, showing the $2 \mathrm{Cd}$ horizon the lowest one (43.7\%), the Ap2y-horizon shows the highest value $(45.8 \%)$. Contrasting with this, the fine-pore volume increases clearly with depth, from 16.2 to $19.4 \%$ of the soil volume. The total water storage capacity reaches within the rooted depth a low value of $138 \mathrm{~mm}$.

The measured water content of the soil is, according to the semi-arid climate, constantly very low, exceeding the PWP only exceptionally. This could be observed only once, in spring of 1997 after a unusual high climatic water excess during the preceding months. In spring and autumn of 1998, the upper $15 \mathrm{~cm}$ (excluding the crust) had a content about 8 Vol.- $\%$ of water, but in summer this decreased to values lower than 3 Vol.-\%.

Additionally, field observations showed no or only a very low volume of macropores, for this the model stars with the assumption of no macro-pores. The parameters used for the modelling are shown in detail in Table 1. The data for the crust was determined according to Carsel \& Parrish (1988) for silt loam material.

The Haplic Gypsisol of the old fallow land shows with depth decreasing hydraulic conductivities from high to medium values. Infiltration rates measured at surface are low-medium, too $\left(\sim 10 \mathrm{~mm} \mathrm{~h}^{-1}\right)$. The porosity is homogenous all over the profile depth. But with a clear decreasing air capacity with depth. The fine pore volume is high in the upper $52 \mathrm{~cm}$, but decreases to $\sim 15 \%$ in the Cy2-horizon. The cumulated available water storage capacity is with $100 \mathrm{~mm}$ over nearly $80 \mathrm{~cm}$ depth low.

The water content of the soil was always below PWP, reaching values between 60 $\mathrm{mm}$ and $10 \mathrm{~mm}$ of stored water in the upper $50 \mathrm{~cm}$, which supposes a water content between $\sim 14 \%$ and $\sim 3 \%$. 


\subsection{Results from modelling}

Modelling on the "young fallow land"

The application of the soil data gained in laboratory (Table 2), assuming no macropores in the soil, led to a total runoff coefficient substantially lower than the one measured in the field experiments. For this, infiltration rate of the soil surface was used instead of the Ksat-value of the A-horizon (see Table 3 for detailed information about the physical soil data in the model input). In this case, the begin of runoff is between 2 min $30 \mathrm{~s}$ and $3 \mathrm{~min} 30 \mathrm{~s}$, little later than the median start of runoff of the simulations (Table 7). The final runoff coefficient was modelled with 0.8 , within the range of measured runoff coefficients (RC) and about the same like the median of the measured RK of the simulations included in this paper (Figure 4). The RK increases rapidly, in a hyperbolic way, until it reaches after only a few minutes a value similar to the final runoff coefficient. It can be observed, that the predicted runoff and the median of the measured runoff are very close during the whole modelled experiment. This indicates that the infiltration-rate decreases, following a hyperbolic decay, very rapidly after runoff begin to very low values. They were calculated at about $4 \mathrm{~mm} \mathrm{~h}^{-1}$. The total amount of water infiltrated is very low, about $4 \mathrm{~mm}$, leading to an increase of soil moisture only in a very shallow superficial fringe of the soil. The final water content modelled was $15 \%$ in $3 \mathrm{~cm}$ depth, $10 \%$ in $9.5 \mathrm{~cm}$ and staying constant at about $7 \mathrm{~cm}$ below $15 \mathrm{~cm}$ (see Figure 5).

Table 3. Physical soil data of the Hyperochric Gypsisol (young fallow land) gained in laboratory.

\begin{tabular}{|cccccccc|}
\hline Horizon & $\begin{array}{c}\text { bulk } \\
\text { density }\end{array}$ & $\begin{array}{c}\text { pore } \\
\text { volume }\end{array}$ & $p F 1.8$ & $p F 2.5$ & $p F 3.0$ & $p F 4.2$ & Ksat $[\mathrm{mm} / \mathrm{h}]$ \\
\hline Ap1y & 1.4 & 45.1 & 11.2 & 6.6 & 11.1 & 16.2 & 38.3 \\
Ap2y & 1.4 & 45.8 & 15.7 & 5.8 & 6.9 & 17.4 & 94.9 \\
2Cd & 1.7 & 43.7 & 4.5 & 1.7 & 18.1 & 19.4 & 7.2 \\
\hline
\end{tabular}
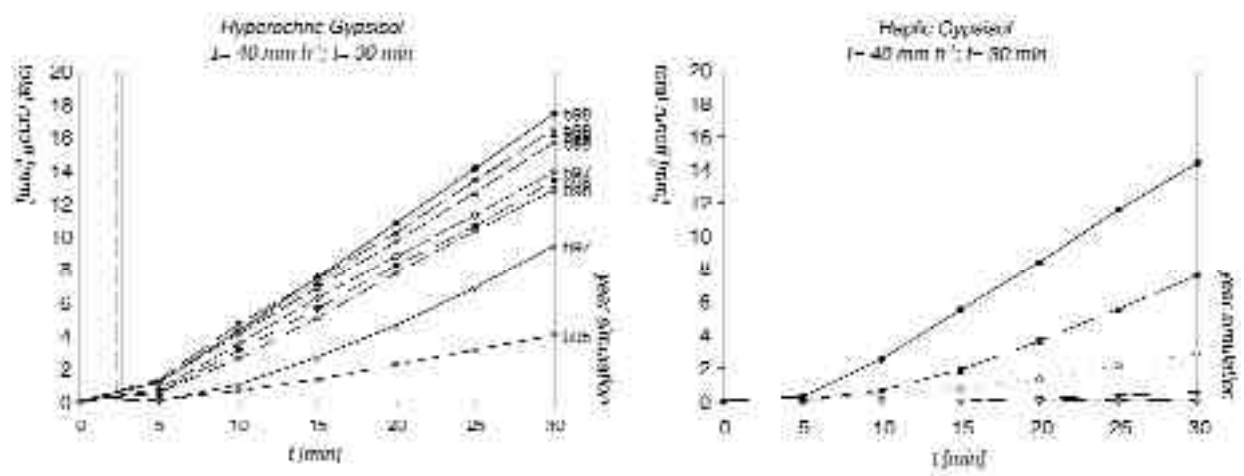

Figure 4. Runoff curves of the rainfall simulations in the Maria de Huerva test site. Left the simulations on the Hyperochric Gypsisol of the young fallow land; right the simulations on the Haplic Gypsisol on the old fallow land. 


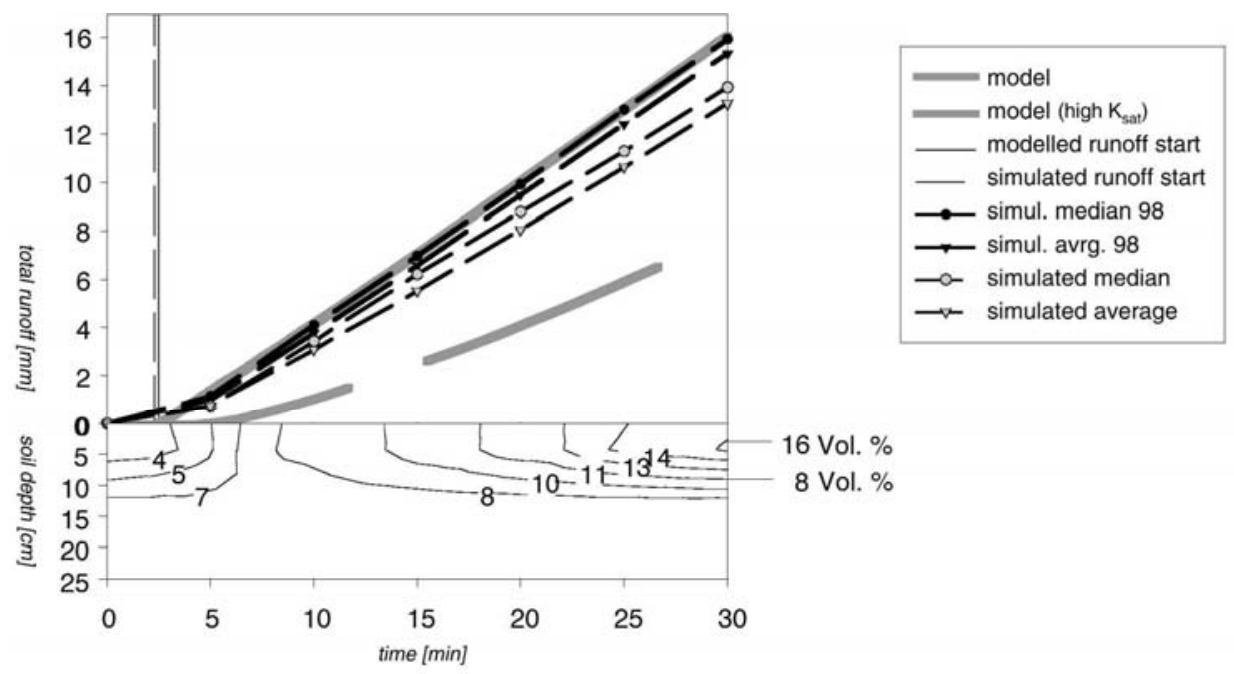

Figure 5. Simulated and modelled rainfall with an intensity of $40 \mathrm{~mm} \mathrm{h-1.} \mathrm{There} \mathrm{are} \mathrm{shown} \mathrm{the}$ modelling results with different Ksat values. The soil moisture dynamic during the simulation is shown at the lower part of the figure.

Modelling infiltration and runoff with different rainfall intensities on the "young fallow land" (Figure 6)

With the calibrated parameters of the rainfall simulation the model was applied for different rainfall intensities. First, the lowest rainfall intensity was determined for which superficial runoff can be expected by iteration. This was at a rainfall intensity of $6 \mathrm{~mm}$ $\mathrm{h}^{-1}$ : after a very late begin of runoff at the $24^{\text {th }} \mathrm{min}$, at a soil moisture in the upper $3 \mathrm{~cm}$ of more than $10 \%$, the total runoff was very low $(\mathrm{RK}=0.02)$ showing a nearly linear increase from runoff begin. Nevertheless, infiltration rates decrease rapidly after runoff begin, reaching at the end of the model a very low value of $4.7 \mathrm{~mm} \mathrm{~h}^{-1}$. The total amount of infiltrated water arises up to $2.9 \mathrm{~mm}$.

With a rainfall intensity of $10 \mathrm{~mm} \mathrm{~h}^{-1}$ runoff begin is modelled in the $11^{\text {th }}$ minute, at a soil modelled soil moisture of less than $8 \%$. The runoff arises up to $30 \%$ of the total

Table 4. Physical soil data of the Haplic Gypsisol (old fallow land) gained in laboratory.

\begin{tabular}{|cccccccc|}
\hline Horizon & $\begin{array}{c}\text { bulk } \\
\text { density }\end{array}$ & $\begin{array}{c}\text { pore } \\
\text { volume }\end{array}$ & $p F 1.8$ & $p F 2.5$ & $p F 3.0$ & $p F 4.2$ & Ksat $[\mathrm{mm} / \mathrm{h}]$ \\
\hline $\mathrm{Ap}$ & 1.4 & 43.3 & 15.5 & 5.0 & 5.5 & 17.3 & 188.8 \\
1By & 1.5 & 43.2 & 12.3 & 4.3 & 5.9 & 20.7 & 38.7 \\
2By & 1.4 & 45.3 & 10.9 & 6.6 & 13.1 & 14.7 & 21.6 \\
\hline
\end{tabular}



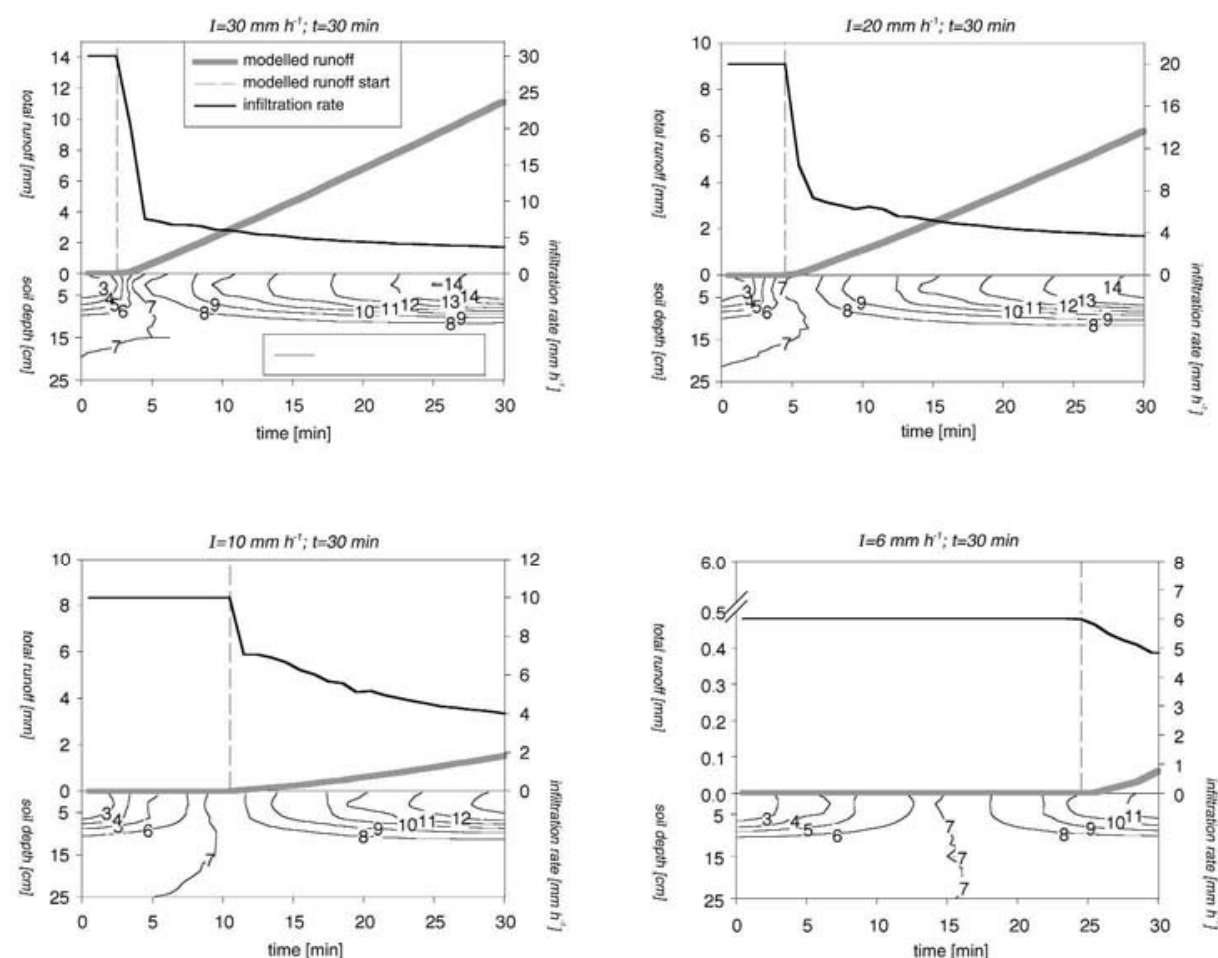

Figure 6. Results of the rainfall simulations at different rainfall intensities.

rainfall, whilst the infiltration rate decreases nearly in a linear way to $4.3 \mathrm{~mm} \mathrm{~h}^{-1}$. So, water recharge into the soil is about $3.5 \mathrm{~mm}$, leading to an increase of soil moisture in the upper $15 \mathrm{~cm}$ where a strong gradient was calculated.

Doubling the precipitation intensity to $20 \mathrm{~mm} \mathrm{~h}^{-1}$ conduces to a very high runoff with a RK of 0.62. Runoff starts within the first $5 \mathrm{~min}$, and the end infiltration rate is with 4 $\mathrm{mm} \mathrm{h}^{-1}$ very low. The reduction of the infiltration rate during the modelled rainfall event is, similar to the experimental results, following a hyperbolic decay curve. The infiltrated amount of water arises up only to $3.9 \mathrm{~mm}$, showing that the moisture increase is limited to the upper $11 \mathrm{~cm}$, reaching in the crust values of more than $14 \%$.

A very strong precipitation of $30 \mathrm{~mm} \mathrm{~h}^{-1}$ leads to an infiltration and runoff behaviour similar to the one simulated with a rainfall intensity of $40 \mathrm{~mm} \mathrm{~h}^{-1}$. The $\mathrm{RK}$ reaches at the end of the modelled experiment 0.73 . Between the $3^{\text {rd }}$ and the $4^{\text {th }}$ minute at a soil moisture of about $6 \%$ at the soil surface the runoff begins, and the total water infiltrated is the same as in the model described above $(3.9 \mathrm{~mm})$. After $30 \mathrm{~min}$ of modelled rainfall the soil moisture arises up to more than $14 \%$ at the topsoil, but beneath $13 \mathrm{~cm}$ depth there can't be no recharge of soil water calculated. The evolution of the infiltration rate shows, that this modelled event is very similar to the one simulated. 
Common of all modelled rainfall intensities is the abrupt decrease of the infiltration rate with the begin of the runoff, and its decrease with time reaching a nearly asymptotic value. Only at low rainfall intensities there can be observed a - nearly - linear decrease of the infiltration rate.

Modelling on the "old fallow land"

Due to the heterogeneity of the rainfall simulations on the "old fallow land" (see Figure 4) there was not possible to parameterise the model with homogenous data for the Haplic Gypsisol. The response to precipitation reacted directly to the variation of the macroporosity of the soil.

A macroporosity of only $0.001 \%$, in combination with the data gained in laboratory (Table 5) and the hydraulic conductivity (Table 6) led to a RC of 0.07. The runoff started during the $6^{\text {th }}$ minute of modelled simulation. The moisture increase is limited to the macroporous layer, being the it very high in the upper $5 \mathrm{~cm}$ of the soil. It can be observed, that the infiltration is dominated by the infiltration into the macropores. The infiltration into the matrix decreases very rapidly to a very low value and shows after this a slight increase.

With an only slightly lower macroporosity $(0.0008 \%)$ the runoff is nearly 3 times higher than in the modelisation before $(\mathrm{RC}=0.18)$, whilst the runoff begin is only one minute earlier. In this case, the increment of soil water shows a similar distribution like

Table 5. Input data of the Hyperochric Gypsisol (young fallow land) for the HILLFLOW 1 Dmodel. There are considered total porosity $\left(\Theta_{\text {sat }}\right)$. rest water content $\left(\Theta_{r^{\prime}}\right.$ here about $\left.p F 7\right)$ satura ted hydraulic conductivity $\left(K_{\text {sat }}\right)$. parameters $\alpha$ and $n$ from parameterisation of the water reten tion curve and the initial soil water content $\left(\Theta_{i n i}\right)$

\begin{tabular}{|llllllll|}
\hline Horizon & $\begin{array}{l}\text { depth } \\
(m)\end{array}$ & $\begin{array}{l}\Theta_{\text {sat }} \\
\left(m^{3 o} m^{-3}\right)\end{array}$ & $\begin{array}{l}\Theta_{r} \\
\left(m^{3 o} m^{-3}\right)\end{array}$ & $\begin{array}{l}K_{\text {sat }} \\
\left(\mathrm{mm}^{o} h^{-1}\right)\end{array}$ & $\begin{array}{l}\alpha \\
\left(m^{-1}\right)\end{array}$ & $n$ & $\begin{array}{l}\Theta_{\text {ini }} \\
\left(m^{3 o} m^{-3}\right)\end{array}$ \\
Apm & 0.03 & 0.35 & 0.02 & 4.6 & 2.0 & 1.141 & 0.02 \\
Ap1y & 0.15 & 0.45 & 0.02 & 38.0 & 19.76 & 1.119 & 0.07 \\
Ap2y & 0.3 & 0.46 & 0.02 & 96.0 & 11.01 & 1.116 & 0.07 \\
2Cd & 0.6 & 0.43 & 0.02 & 7.0 & 0.05 & 1.341 & 0.08 \\
\hline
\end{tabular}

Table 6. Input data of the Haplic Gypsisol (old fallow land) for the HILLFLOW 1 D-model. There are considered total porosity $\left(\Theta_{\text {sat }}\right)$. rest water content $\left(\Theta_{r}\right.$. here about $p F$ 7) saturated hydraulic conductivity $\left(K_{\text {sat }}\right)$. parameters $\alpha$ and $n$ from parameterisation of the water retention curve and the initial soil water content $\left(\Theta_{i n i}\right)$. In this case the soil macroporosity was set to 0.001 $\%$ and $0.0008 \%$ to a depth of $0.25 \mathrm{~m}$.

\begin{tabular}{|llllllll|}
\hline Horizon & $\begin{array}{l}\text { depth } \\
(m)\end{array}$ & $\begin{array}{l}\Theta_{\text {sat }} \\
\left(m^{3 o} m^{-3}\right)\end{array}$ & $\begin{array}{l}\Theta_{r} \\
\left(m^{3 o} m^{-3}\right)\end{array}$ & $\begin{array}{l}K_{\text {sat }} \\
\left(\mathrm{mm}^{o} h^{-1}\right)\end{array}$ & $\begin{array}{l}\alpha \\
\left(m^{-1}\right)\end{array}$ & $n$ & $\begin{array}{l}\Theta_{\text {ini }} \\
\left(m^{3 o} m^{-3}\right)\end{array}$ \\
Apm & 0.005 & 0.41 & 0.02 & 10.2 & 2.0 & 1.141 & 0.04 \\
Ap & 0.28 & 0.43 & 0.02 & 189.0 & 43.7 & 1.235 & 0.07 \\
1By & 0.52 & 0.43 & 0.02 & 39.0 & 39.98 & 1.176 & 0.07 \\
2By & 0.76 & 0.45 & 0.02 & 22.0 & 8.73 & 1.432 & 0.08 \\
\hline
\end{tabular}


the one described before, of course being lower. The infiltration dynamics is the same, too, being the macropore-infiltration predominant along nearly the whole modelisation.

Due to the uncertainty of the parameterisation of the soils for modelling the response to rainfalls the modelisation of rainfall of lower intensities was not performed. It can be observed, that the infiltration capacity of the macropore-layer is about $33.6 \mathrm{~mm} \mathrm{~h}^{-1}(0.001$ $\%$ macropores) and $26.9 \mathrm{~mm} \mathrm{~h}^{-1}(0.0008 \%$ macropores $)$, so these have to be considered as lowest rainfall intensities able to generate superficial runoff.

\section{Discussion and Conclusions}

The results of the combination of field observations, simulation of rainfall and its modelisation give wide information about the response of the soils to precipitation. The sparsely vegetation-covered soils of a 6-year old abandoned cereal field are very homogenous in their physical characteristics. The crust created by the effect of the antecedent rainfall determinates the runoff generation. This crust reduces the infiltration capacity of the topsoil considerably, and its hydraulic conductivity tends to decrease with time. The modelisation results indicate that runoff is generated at least by rainfall intensities higher than $10 \mathrm{~mm} \mathrm{~h}^{-1}$ of a duration longer than $15 \mathrm{~min}$. This values may decrease during the event as an effect of the sealing of the crust during precipitation and by the decrease of the hydraulic gradient in the upper centimetres of the soil. This effect was well calculated by the model. On the other hand, rainfall intensities of $30 \mathrm{~mm} \mathrm{~h}^{-1}$ and more lead to a very fast and high runoff generation (Figure 7).

The infiltration of water into this soils is always very low and shallow, leading to a significant limitation of soil water recharge during the rainfalls. If it is taken account that the atmospheric water deficit is always high, the constant drought of the soils all along the year can be explained.

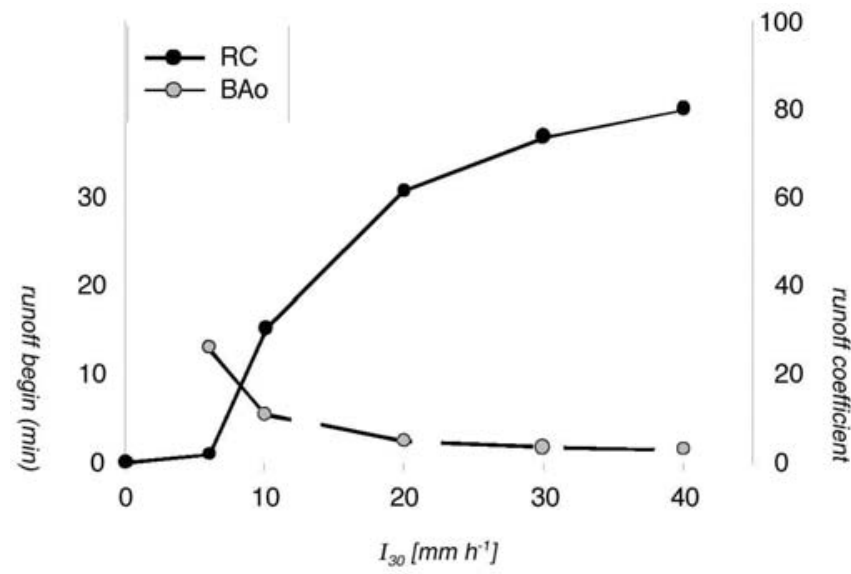

Figure 7. Comparison of the different rainfall intensities modelled. The final runoff coefficient and the runoff start is shown. 
Table 7. Characteristic data of the rainfall simulations. Slope in degrees, moisture in Vol.-\%, BegAo is beginning of runoff in minutes, Inf. Depth is infiltration depth, $R C$ the runoff coefficient.

\begin{tabular}{|llccccc|}
\hline & date & slope & moisture & BegAo & Inf. depth & RC \\
\hline "young fallow land" & 06.10 .95 & 2 & 4.5 & 3.40 & 3 & 20.0 \\
& 28.03 .97 & 4 & 5.5 & 3.57 & 4 & 49.3 \\
& 23.07 .97 & 5 & 3.5 & 3.40 & 10 & 74.8 \\
& 04.04 .98 & 7 & 1.8 & 2.15 & 4 & 81.3 \\
& 04.04 .98 & 7 & 1.7 & 2.32 & 4 & 73.9 \\
& 05.04 .98 & 7 & 6.4 & 2.06 & 7 & 81.0 \\
& 05.04 .98 & 7 & 4.8 & 2.10 & 3 & 65.6 \\
& 02.08 .98 & 7 & 6.2 & 3.00 & n.B. & 68.5 \\
& 15.10 .98 & 2 & n.B. & 1.43 & n.B. & 77.0 \\
& Average & 5.3 & 4.3 & 2.6 & 5.0 & 65.7 \\
& Median & 7 & 4.65 & 2.32 & 4 & 73.9 \\
& 08.10 .95 & 3 & 7.3 & 5.00 & 3 & 14.5 \\
& 31.03 .97 & 2 & 5.8 & 6.08 & 23 & 0.2 \\
& 01.04 .97 & 10 & 5.8 & 4.45 & 9 & 36.5 \\
& 25.07 .97 & 5 & 7.4 & 15.04 & 40 & 2.5 \\
& 08.04 .98 & 4 & 4.3 & 3.10 & 2 & 67.2 \\
& Average & 4.8 & 6.12 & 6.7 & 15.4 & 24.2 \\
& Median & 4 & 5.8 & 5.0 & 9 & 14.5 \\
\hline
\end{tabular}
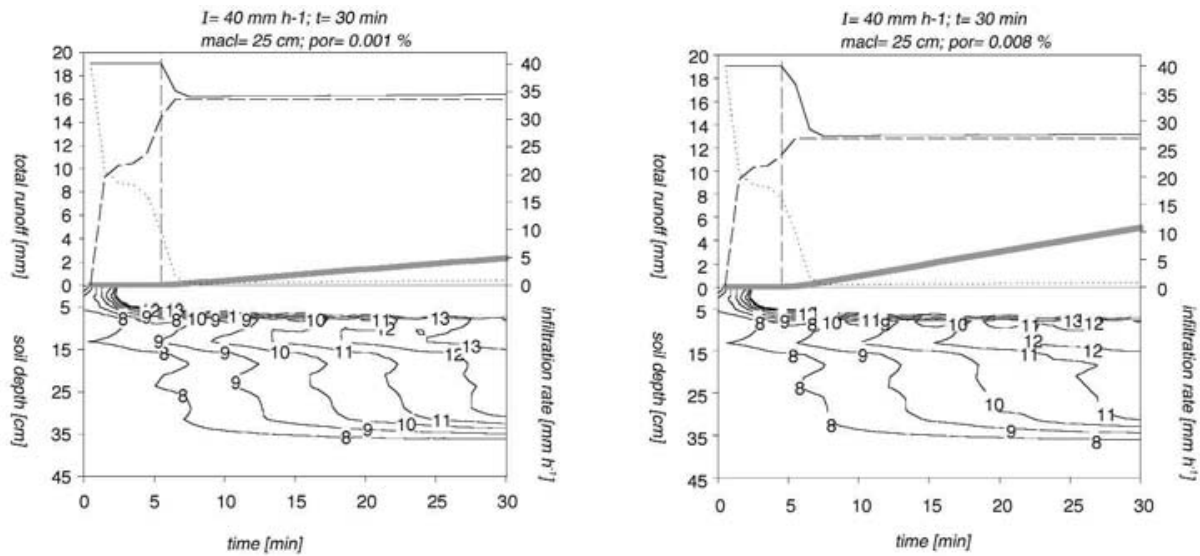

Figure 8. Results from the modelling of rainfall simulations on the old fallow land with different macropore volume. In addition, infiltration rates into the matrix and into the macropores are shown.

On the other hand, the soils of a 60 -year old fallow land show some characteristics very different to the ones described above. The simulation results indicate a very high variability of physical characteristics in space. The shallow crust restrains the infiltration into the matrix, but at the same time, the macroporosity created by soil-animals makes possible an infiltration into the soil, even into deeper layers. For this, the high variabili- 
ty of the runoff measured by simulation can be explained by a high variability in macropore distribution. Deep and interconnected macropores may cause a rapid flow in the soil, without a significant water recharge into the matrix. As a consequence, piping processes may be enhanced, as it can be observed in the field: deep gullies erode the old abandoned fields.

The results of the modelisation of rainfall on the "old fallow land" shows, at the same time, the limitation of physical based hydraulic models. The accuracy required for the soil data is partly impossible to gain with conventional field methods. Infiltration processes into extreme dry soils, with air inclusions in the macropores, with hydrophobity effects of the matrix, may influence very strongly the infiltration processes and have to be taken account in models. The ongoing with a separated simulation of flows in matrix and macropores, with the consequent quantification of macropore volume, has to be considered. It seems to be more operable to quantify the variation of the hydraulic conductivity as a function of moisture and inclusion of macropores like proposed in CATFLOW. Nevertheless, the combination of the modelisation with simulation experiments enhances the understanding of infiltration and runoff-generation processes.

It is obvious now, that crust-formation has to be inhibited to enhance the infiltration of water into the soils of the abandoned farmlands of the semi-arid Inner Ebro Depression. At the same time a rapid recovery of vegetation and soil-animal population is necessary to enhance soil protection and physical characteristics. For this the, now usual, ploughing with set-aside programs has to be stopped as well as additional measures have to been undertaken, like artificial increment of soil organic matter, e.g. by application of sewage sludge or similar. The land management before abandonment is, on the other hand, very important for this purpose, too. The introduction of reduced tillage techniques or similar is a measure, which introduces rapidly high quantities of organic matter into the soils.

\section{Acknowledgements}

This work was supported by the project EPRODESERT, financed by the German Scientific Fund (DFG, Ri 95/1-3). M. Seeger was granted by the German Service for Academic Exchange (DAAD) and the state of Baden-Württemberg (GraFöG).

\section{References}

Arbeitsgruppe Boden (Ed.) (1994). Bodenkundliche Kartieranleitung. 4th ed., Reprint 1996, 392 pp..

Bork, H.R. (1988). Bodenerosion und Umwelt. Verlauf, Ursachen und Folgen der Mittelalterlichen und neuzeitlichen Bodenerosion - Bodenerosionsprozesse-Modelle und Simulationen. (= Landschaftsgenese und Landschaftsökologie, 6), 294 pp., Braunschweig.

Bronstert, A. (1994). Modellierung der Abflußbildung und der Bodenwasserdynamik von Hängen. (= IHW, 46), 252 pp., Karlsruhe. 
Bronstert, A., Glüsing, B. and Plate, E. (1998). Physically-based hydrological modelling on the hillslope and micro-catchment scale: examples of capabilities and limitations. In: Proceedings of: Hydrology, Water Resources and Ecology in Headwaters (HeadWater '98 Conference), Meran/Merano; IAHS Publ. 248: 207-215.

Calvo, A. B., Gisbert, E., Palau, E. and Romero, M. (1988). Un simulador de lluvia portátil de fácil construcción. In: Sala, M. and Gallart, F. (Eds.): Métodos y técnicas para la medición de procesos geomorfológicos, Sociedad Española de Geomorfología,pp. 6-15, Barcelona.

Carsel, R. and Parrish, R. (1988). Developing joint probability distributions of soil water retention characteristics. Water Resources Research, 24 (5): 755-769.

Link, M. (1999). Das Einringinfiltrometer mit schwimmergeregelter Überstauhöhe Vorteile und technische Daten eines neuen Geräts zur Messung von Infiltrationsraten in Böden. In: Ries, J.B. (Ed.): EPRODESERT - Bodenwasserhaushalt und aktuelle Geomorphodynamik auf Brachflächen in Aragón/Spanien. APT-Berichte, 10: 41-50.

NSSC (National Soil Survey Center) (Ed.) (1996). Soil Survey Laboratory Methods Manual. Soil Survey Investigations Report, 42, 716 pp., Washington.

Richards, L. A. (1931). Capillary conduction of liquids through porous mediums. Physics, 1: 318-333.

Ries, J. B., Langer, M. and Rehberg, C. (2000). Experimental investigations on water and wind erosion on abandoned fields and arable land in the central Ebro Basin, Aragón/Spain. Z. Geomorph. N. F., 121: 91-108.

Ruiz-Flaño, P. (1993). Procesos de erosión en campos abandonados del Pirineo. El ejem plo del Valle de Aísa. Geoforma Ediciones, 191 pp., Logroño.

Seeger, M. (2001). Boden und Bodenwasserhaushalt als Indikatoren der Landdegradierung auf extensivierten Nutzflächen in Aragón / Spanien. Freiburger Geographische Hefte, 63: $184+30$ p.

Soilmoisture Equipment (1990). Trase 1. Operating Instructions. Moisture measurement for agriculture and earth sciences by time domain reflectometry. 53 pp., Santa Barbara.

van Genuchten, M. Th., F. J. Leij, and S. R. Yates (1991). The RETC Code for Quantifying the Hydraulic Functions of Unsaturated Soils, Version 1.0. EPA Report 600/2-91/065, U.S. Salinity Laboratory, USDA, ARS, Riverside, California.

van Genuchten, M.Th. (1980). A closed-form equation for predicting the hydraulic conductivity of unsaturated soils. Soil Sci. Soc. Am. J., 44: 892-898. 